\title{
Assessment model of regions' economy in the context of their sustainable development
}

\author{
Pavlo Hryhoruk ${ }^{1, *}$, Nila Khrushch $^{2}$, and Svitlana Grygoruk $^{3}$ \\ ${ }^{1}$ Khmelnytskyi National University, Department of Automated Systems and Modeling in Economics, Khmelnytskyi, 29016, Ukraine \\ ${ }^{2}$ Khmelnytskyi National University, Department of Finance, Banking and Insurance, Khmelnytskyi, 29016, Ukraine \\ ${ }^{3}$ Khmelnytskyi National University, Department of Software Engineering, Khmelnytskyi, 29016, Ukraine
}

\begin{abstract}
Currently realizing the new active role of the region as a sustainable development entity is a strategic direction for regional policy's development. Assessing the sustainable development of regions is an important part of such a policy and facilitates the timely identification of internal and external threats, the development of the necessary stabilization measures to prevent their negative impact, and the formation of strategies aimed at the sustainable functioning of regional systems. The economic system is an important subsystem of the region. The article proposes an approach to assess the level of regions economic development in the context of ensuring its sustainable development. It is based on comprehensive assessment technology. The sustainable economic development composite index is calculated by a weighted additive convolution of partial indicators. A feature of the proposed approach is the simultaneous use of both metric and nonmetric indicators. The metric component is used to calculate the composite index values. Weight coefficients are calculated by the principal component method using the factor loadings of the first principal component. The non-metric part of the initial data is used to refine these weights. The article describes the algorithm for calculating a composite index. The practical testing of the proposed approach is presented for the case Ukraine's regions. The results lead to the conclusion about significant problems in ensuring sustainable development of the regional economy. Outcomes obtained are very helpful for the public administration bodies to develop and revise the appropriate policy for solving the sustainable development problems in each region.
\end{abstract}

\section{Introduction}

Sustainable development is a modern worldview, political and practical model of development for all countries of the world, which have started the transition from a purely economic model of development to finding the optimal balance between the three components of development economic, social and environmental. This category is perceived around the world as a model of civilized development. Implementation of this model requires the formation of a system for managing such development.

In September 2015, during the 70th session of the UN General Assembly in New York, the UN Summit on Sustainable Development took place and adopted the 2030 Agenda for Sustainable Development. It approved new development benchmarks [1]. Summit issues covered all aspects of socio-economic development, in particular, countries' competitiveness, environmental and energy security, global partnership for development, and were based on the principle of "Leaving no one behind". Summit Outcome Document contains 17 Sustainable Development Goals. This led to the update of the
Sustainable Development Strategy of Ukraine until 2030 [2]. The Strategic vision of Sustainable Development of Ukraine is focused on overcoming the imbalances that exist in the economic, social, environmental spheres and is based on the vectors defined in the Sustainable Development Strategy "Ukraine 2020" [3], one of which is the vector of development. It foresees sustainable development of the country, carrying out structural reforms, ensuring economic growth in an environmentally sustainable way, creating favorable conditions for economic activity [2].

Thus, at the present stage of development of Ukraine's economy, the problem of transition to sustainable development of both the country as a whole and each of its regions is urgent. The balanced regions development should be oriented towards providing conditions that will allow each region of the country to have the needed and sufficient resources to ensure decent living conditions, comprehensive development and increase the competitiveness of the economy.

On the one hand, sustainable development of the region may be seen as a positively directed process of

\footnotetext{
* Corresponding author: violete@ukr.net
} 
improving the economic, social and environmental components. On the other hand, it is considered as a process to achieve balanced state for all of these components.

The assessment of the level and state of sustainable development of regions' economy is necessary to identify internal and external threats, which will allow to devise measures to prevent their negative impact in order to identify scenarios of development and to develop an optimal strategy for the functioning of country's regional economic systems.

\section{Literature review}

The issue of assessing the level of sustainable development, both at the national and regional levels, remains a subject of many scholars' studies. Economic, social and environmental components have traditionally been taken into account for regional systems. In our study, the focus will be on assessing the economic component of regional development in the context of its sustainable development. We support the point of view of A. M. Zhuchenko [4, p. 432] that sustainability is understood as a property or quality that determines the ability of a regional system to be in a state of dynamic equilibrium in the presence of external and internal influences. Sustainability may be inherent not only in the fixed state of the regional system but also in its changes. As the main types of such stability can be distinguished as: the stability of development, characterized by a systematic increase in the result, which is not lower than the acceptable minimum and not higher than the objectively determined maximum; as permanent stability when changes, including positive ones, occur only occasionally and for a short time; as hyper-sustainability like a state where regions are not susceptible to development but are able to adapt to changes, including positive ones.

The analysis of publications [5-16] showed a variety of methodological approaches to assess sustainable development, which is determined by the identified goals to obtain evaluations. At the same time, most of the methodological approaches involve to calculate a composite (integrated, comprehensive) index of sustainable development based on the use of additive or multiplicative convolution. In some cases, the author's techniques involve the analysis of the output without the convolution, in particular, the indicative method of evaluation. In our view, narrowing the assessment outcome to a single indicator makes it easier to draw conclusions, but on the other hand, this approach causes a "compensation effect" when the low values of some indicators are offset by the high values of other ones. This disadvantage can be partially eliminated by using a weighted convolution of the initial indicators.

The paper [5] proposes a methodological approach to the assessment of sustainable development of Ukrainian regions, in which the overall assessment of its level is carried out using a composite index, based on the additive convolution of indicators of social, economic and environmental components. An integrated assessment of the sustainable development of the Ukraine's regions is carried out and problems of regions development in the social, economic and environmental fields are identified. It should be noted that the author proposes to use the financial statements, which, in our opinion, limits the application of the proposed methodology.

A. V. Horiana [6] distinguishes infrastructure and innovation components in addition to the traditional part of sustainable development to design a composite index. Author defines the rules of composite index calculation based on the multiplicative convolution and formulates the conditions under which sustainable development is reached. A similar approach is implemented in paper [7]. However, these approaches leave open the issues of identification the required set of initial data.

Study of O. Nesterenko [8] uses an approach based on the scoring model to assess the sustainable development composite index. At the same time, the author proposes to use both the statistical reporting indicators and questionnaires outcomes of evaluation of the several components of sustainable development. Commonly proposed method uses recognized indicators of human development like the Knowledge Index, the Human Capital Development Index, and the Human Development Index. It should be noted, that some of the used indicators have a non-numerical origin and therefore their mathematical processing is not always correct.

Papers $[9,10]$ proposed a set of criteria for assessing the sustainable development of a region based on the use of both metric and non-metric indicators. But authors do not specify the rules for processing data and constructing the resulting metric.

The experience of foreign scholars in solving the problems of sustainable development assessment is presented in [11-16]. In particular, paper [11] presents the author's methodology for assessing sustainable development for the Czech Republic according to four components: Political area, Social area, Economic area and Environmental area, which uses 101 output indicators and provides for the calculation of a hierarchical integral index system, which includes 12 partial indicators, 4 partial composite indicators and one aggregate integrated index of sustainable development.

Study [12] presents an original approach to the calculation of a comprehensive sustainable development index based on the case of Indonesia's regions. Authors propose three measures for indices: arithmetic, geometric and entropy-based. Indices are aggregated to use for comparing regions in terms of their stability. The article also analyzes the sensitivity of the results obtained. It should be noted that despite the ranking of regions by the value of the integrated indicator of sustainable development, the authors were not offered a scale to estimate the level of sustainable development of regions. An alternative approach to assess the sustainable development of Indonesia's regions is given in paper [13]. It is based on a combination of factor analysis and cluster analysis methods. First method is used to construct partial composite indices of sustainable development by each of its component, and the cluster analysis is used to group regions by the level of sustainable development. Authors propose to use the resulting cluster map of regencies and 
municipalities to make a decision in order to identify appropriate policies to address problems in each region.

Studies [14-16] have presented approaches for assessing the degree of achievement of the 17 Sustainable Development Goals identified in [1] in a case of Asian countries.

The conducted analysis of publications makes it possible to conclude that the presented approaches are based on the UN Sustainable Development Concept using some differences in the structure of components and the number of partial indicators. Advantages of the composite indexes for evaluation of various aspects of sustainable development include the simplicity of their calculation and the ease of results interpretation. However, the approaches don't contain criteria for identifying the level of sustainable development. A significant disadvantage of these methods is the use of an overloaded set of partial indicators, which, moreover, don't always correspond to the system of national statistics. Tis fact creates a multiplier effect and complicates the assessment in dynamics. There is also a methodological problem to select indicators to be included to the index and with the identification of weights of partial indicators.

The results of this review cause to develop our own approach to assess the region economy in the context of its sustainable development.

\section{Problem description and methodology}

To assess the economic development of the regions, we propose an approach based on the calculation of the composite index. An important step in its design is the shaping of an information base that includes a set of initial partial indicators that characterize sustainable development. It should be noted that an excessive number of initial partial indicators reduces ability of composite index to account of the variability of the components. In addition, the use of a weighted convolution may either lead to the elimination of differences between their importance or to the loss of statistical significance of some of them. Also, we note, that some of the initial data may have a non-numerical origin, which causes to take into account the non-metric indicators in calculations.

We propose an approach to design an integral metric to assess the regions' economic development by considering both metric and non-metric indicators. In this case, the metric part of the set of partial indicators will be used to calculate the numerical values of the composite index, and the non-metric component of this set will be used to specify the weighting coefficients of metric indicators in their convolution. The construction of a composite index is carried out by using a weighted convolution of the initial metric indicators. We use the principal components method to calculate their primary weights in order to take into account in convolution. Calculation of the weight coefficients values is made in proportion to the factor loadings of the initial indices of the first principal component. The final values of weight coefficients are executed with taking into account the correlation coefficients between numeric indicators and non-metric ones.
The designing procedure for composite index is implemented by the following algorithm.

1) Identifying set of partial indicators:

$$
\begin{gathered}
X=\left\{X^{(1)} \mid X^{(2)}\right\}= \\
\left\{X_{1}^{(1)}, X_{2}^{(1)}, \ldots, X_{k 1}^{(1)}, X_{1}^{(2)}, X_{2}^{(2)}, \ldots X_{k 2}^{(2)}\right\}
\end{gathered}
$$

where $X^{(1)}=\left\{X_{i}^{(1)}\right\}$ is a subset of metric (nimerical) indicatots, $i=1,2, \ldots, k_{1} ; X^{(2)}=\left\{X_{i}^{(2)}\right\}-$ is a subset of nonmetric indicatots, $i=1,2, \ldots, k_{2} ; k_{1}, k_{2}-$ appropriate numbers of indicators in each part of initial set, $k_{1}+k_{2}=n$;

$n$-common number of indicators.

We proposed to include indicators measured on a rank scale to the non-metric part of this set.

2) Calculating correlation matrix $R$ for metric subset initial data. To reach this aim, we propose to use Pearson's correlation coefficients.

3) Calculating the correlation coefficients values $\rho_{i j}$ between metric $X_{i}^{(1)}$ and non-metric $X_{j}^{(2)}$ indicators, $i=1,2, \ldots, k_{1} ; j=1,2, \ldots, k_{2}$. To reach this aim, we propose to use Spearman's rank correlation coefficients or Kendall's ones. In the case, when the construction of initial data non-metric part is carried out based on the expert evaluations, additionally we shoud assess the consistency of expert opinions by calculating the concordance coefficient. In the case of the dichotomous indicators (as a partial case of using rank scale), it is advisable to use a point-biserial correlation coefficient as a measure of interrelation between components of each part of initial data.

4) Normalization of metric indicators by reducing their values to a range from 0 to 1 , with the formation of conformity of their increasing values to better quality. This procedure is necessary for the constructed composite index to be within $[0 ; 1]$ and had a positive correlation with each of the initial components. In addition, the normalized values should be invariant to the units of measurement. Normalization can be done in different ways. The most common approach uses the conversion of initial data using the largest and / or smallest sample values [17]. The way of normalization depends on the origins of the initial indicators and their range of values. If the simple has a boundary or normative values limiting the growth of their positive quality, we may use the approach given in [18].

5) Designing a composite index using the following four-step procedure. The first step is to calculate the first principal component for a subset of metric indicators. It is known that it corresponds to the first (largest on absolute value) eigenvalue $\lambda_{1}$ of the correlation matrix $R$. In the second step, the factor loadings of the first principal component are calculated:

$$
W=\left\{w_{1}, w_{2}, \ldots, w_{k 1}\right\} .
$$

In the case when the number of initial metric indicators is large enough, the use of all of them for the calculation of the composite indicator is impractical for the reasons stated above. It is recommended to select the most informative ones using the rule: 


$$
\left|w_{i}\right| \geq \delta,
$$

where $\delta$ is a given level of factor loading significance; $i=1,2, \ldots, k_{1}$.

On the third step, we carry out the calculation of weight coefficients for metric initial indicators. These values are calculated taking into account the influence of non-metric indicators that were included to the appropriate part of initial set of data:

$$
\alpha_{i}^{\prime}=\left|w_{i}\right| \cdot\left|\prod_{j=1}^{k_{1}} \rho_{i j}\right|^{1 / k_{1}}
$$

where $w_{i}$ is a factor loading of first principal component for $i$-th metric indicator of subset $X^{(1)}, \rho_{i j}$ - value of the rank correlation coefficient between $i$-th metric component of subset $X^{(1)}$ and $j$-th non-metric component of subset $X^{(2)} ;|z|-$ absolute value of $z$.

Since the obtained values of $\alpha_{j}^{\prime}$ in total may differ from 1 , we carry out their normalization:

$$
\alpha_{i}=\frac{\alpha_{i}^{\prime}}{\sum_{j=1}^{k_{1} \alpha_{j}^{\prime}},}
$$

$i=1,2, \ldots, k_{1}$.

On the fourth step, we calculate a composite index using one of the ways for convolution of initial numeric indicators:

$$
\begin{gathered}
I=\sum_{i=1}^{k_{1}} \alpha_{i} U_{i}, \\
I=\prod_{i=1}^{k_{1}} U_{i}^{\alpha_{i}}, \\
I=-1+\prod_{i=1}^{k_{1}}\left(1+U_{i}\right)^{\alpha_{i}},
\end{gathered}
$$

where $U_{i}$ - normalized values of metric indicators $X_{i}^{(1)}$, $i=1,2, \ldots, k_{1}$. Formula (6) present additive convolution, formulas (7) and (8) - multiplicative ones. It is also quite common to calculate the composite index using the distance method, but on our opinion, in this case its use is impractical, since this method involves the use of some "ideal" point, which is the standard of the studied quality. There is no sense of existence of such a point for considered problem.

\section{Findings}

Using the proposed approach to the design of a composite index, let we evaluate the economic development of the regions in the context of their sustainable development. As noted above, the sustainable development of a region may be seen as a process of improving the functioning all of its subsystems, including the economic one. For these reasons, we form a set of initial indicators. Obvious characteristics of development are relative indicators of dynamics, in particular, growth rates. However, we take into account, that usually such indicators have low variability within the country's economic system. So, in our view, it is more appropriate to use indicators of relative percentage increases.

Another problem that needs to be addressed in the formation of an information base for comprehensive assessment is the identification of the set of initial indicators. In our opinion, the subsystem of metric indicators should include those indicators that characterize the most important features of the regional economic system like GRP, industrial and agricultural production, investment and foreign economic activity.

Recently, it is quite common to use various rating evaluations, which reflect the level of regional development. They are calculated on the basis of the main indicators of the functioning of all regional subsystems. In particular, such estimates are submitted by the Ministry of Communities and Territories of Ukraine [19, 20]. They may be used as non-metric indicators of economic development.

Thus, for the purposes of calculations we have formed the following set of indicators: $Y_{1}^{(1)}-$ Index of factual volume of GRP in previous year prices, percent; $Y_{2}^{(1)}$ Capital investment index, percent; $Y_{3}^{(1)}-$ Industrial production index, percent; $Y_{4}^{(1)}-$ Agricultural production index; percent; $Y_{5}^{(1)}-$ Foreign direct investment index, percent; $X_{1}^{(2)}-$ Investment and innovation development and foreign economic cooperation (rank); $X_{2}^{(2)}-$ Financial self-sufficiency (rank); $X_{3}^{(2)}$ - Labor market efficiency (rank).

The data source for determining metric indicators were materials of the State Statistics Service of Ukraine [21], and for non-metric indicators - sources [19, 20].

To provide calculations, metric indicators are converted to indicators of relative percentage increases by rule:

$$
X_{i}^{(1)}=Y_{i}^{(1)}-100
$$

$i=1,2, \ldots, 5$.

In order to compact reflection of information we assign a code to each region. The relevant information is shown in Table 1. Values of metric indicators converted by formula (9) are shown in Table 2, and the values of non-metric indicators are shown in Table 3.

Table 1. Relations between title of regions and their codes.

\begin{tabular}{|l|l|l|l|}
\hline Code & \multicolumn{1}{|c|}{ Region } & Code & \multicolumn{1}{|c|}{ Region } \\
\hline C_1 & Vinnytsia & C_13 & Mykolaiv \\
\hline C_2 & Volyn & C_14 & Odesa \\
\hline C_3 & Dnipro & C_15 & Poltava \\
\hline C_4 & Donetsk & C_16 & Rivne \\
\hline C_5 & Zhytomyr & C_17 & Sumy \\
\hline C_6 & Zakarpattia & C_18 & Ternopil \\
\hline C_7 & Zaporizhzhia & C_19 & Kharkiv \\
\hline C_8 & Ivano-Frankivsk & C_20 & Kherson \\
\hline C_9 & Kyiv & C_21 & Khmelnytskyi \\
\hline C_10 & Kyrovohrad & C_22 & Cherkasy \\
\hline C_11 & Luhansk & C_23 & Chernivtsi \\
\hline C_12 & Lviv & C_24 & Chernihiv \\
\hline
\end{tabular}

To reach normalized data we use the next rule:

$$
u_{i j}=\frac{x_{i j}-x_{\text {min }}}{x_{\text {jmax }}-x_{\text {jmin }}},
$$


where $u_{i j}$ is a $i$-th normalized value of indicator $X_{j}^{(1)} ; x_{i j}$ is a $i$-th initial value of indicator $X_{j}^{(1)} ; x_{\text {jmax }}$ and $x_{\text {jmin }}$ are maximal and minimal values of indicator $X_{j}^{(1)} ; i=1,2, \ldots$, $24 ; j=1,2, \ldots, 5$. We conduct the normalization process for data of each year. We denote normalized indicators as $U_{j}, j=1,2, \ldots, 5$. In doing so, we have taken into account the fact that all of initial indicators are incentive.

Table 2. Values of metric indexes for data of 2016-2018 transformed by formula (9).

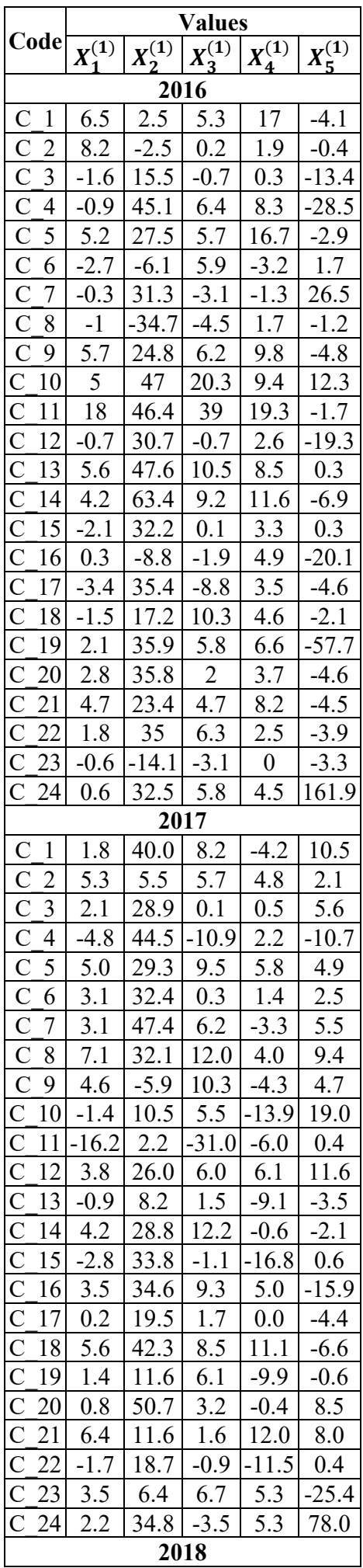

\begin{tabular}{|l|r|r|r|r|r|}
\hline \multirow{2}{*}{ Code } & \multicolumn{5}{|c|}{ Values } \\
\cline { 2 - 6 } & $\boldsymbol{X}_{\mathbf{1}}^{(\mathbf{1})}$ & $\boldsymbol{X}_{\mathbf{2}}^{(\mathbf{1})}$ & $\boldsymbol{X}_{\mathbf{3}}^{(\mathbf{1}}$ & $\boldsymbol{X}_{\mathbf{4}}^{(\mathbf{1})}$ & $\boldsymbol{X}_{\mathbf{5}}^{(\mathbf{1})}$ \\
\hline C_1 & 6.4 & 37.8 & -0.8 & 10.6 & 12.3 \\
\hline C_2 & 3.3 & 12.1 & 2.2 & 3.2 & 3.3 \\
\hline C_3 & 2.5 & 29.4 & 3.0 & 2.7 & -3.0 \\
\hline C_4 & 0.9 & 54.6 & 2.6 & -9.4 & 8.0 \\
\hline C_5 & 6.1 & 2.4 & -2.5 & 11.9 & 4.7 \\
\hline C_6 & 4.7 & 17.3 & 5.1 & 7.0 & 4.6 \\
\hline C_7 & 1.9 & -12.0 & 3.6 & -14.4 & -0.9 \\
\hline C_8 & 5.8 & -15.3 & 10.3 & 1.3 & -1.1 \\
\hline C_9 & 6.5 & 9.8 & 2.0 & 23.8 & 0.2 \\
\hline C_10 & 5.8 & -9.0 & 2.2 & 20.6 & 6.3 \\
\hline C_11 & 1.0 & -8.4 & -17.0 & 9.2 & -0.3 \\
\hline C_12 & 5.4 & 1.9 & 2.4 & 3.8 & -0.8 \\
\hline C_13 & 4.1 & -12.6 & 4.0 & 6.0 & 10.3 \\
\hline C_14 & 0.9 & -4.1 & -7.6 & 1.1 & 0.4 \\
\hline C_15 & 5.8 & 5.5 & 1.5 & 24.0 & 1.8 \\
\hline C_16 & 0.6 & 8.7 & -4.4 & 2.5 & -0.5 \\
\hline C_17 & 3.9 & 8.5 & 10.3 & 11.5 & 0.7 \\
\hline C_18 & 2.0 & 3.7 & -1.8 & 3.9 & 24.1 \\
\hline C_19 & 1.8 & 9.3 & 2.9 & 6.0 & 4.4 \\
\hline C_20 & 0.6 & -10.7 & 1.1 & 0.5 & -6.6 \\
\hline C_21 & 1.2 & -3.5 & -4.7 & 2.6 & 16.8 \\
\hline C_22 & 5.7 & 32.4 & 2.3 & 22.8 & -0.4 \\
\hline C_23 & 4.5 & 6.7 & 5.8 & 5.3 & 3.4 \\
\hline C_24 & 4.2 & 17.7 & -0.8 & 11.1 & 1.0 \\
\hline & & & & & \\
\hline
\end{tabular}

Table 3. Values of non-metric indexes for data of 2016-2018.

\begin{tabular}{|l|c|c|c|c|c|c|r|r|r|}
\hline \multirow{2}{*}{ Code } & \multicolumn{10}{|c|}{ Values } \\
\cline { 2 - 9 } & \multicolumn{2}{|c|}{2018} & \multicolumn{2}{|c|}{$\mathbf{2 0 1 7}$} & \multicolumn{2}{|c|}{$\mathbf{2 0 1 6}$} \\
\hline C_1 & 19 & 6 & 9 & 10 & 4 & 15 & 2 & 5 & 3 \\
\hline C_2 & 20 & 18 & 21 & 21 & 5 & 23 & 16 & 24 & 17 \\
\hline C_3 & 4 & 7 & 3 & 2 & 3 & 3 & 5 & 2 & 2 \\
\hline C_4 & 9 & 23 & 24 & 3 & 23 & 24 & 1 & 4 & 23 \\
\hline C_5 & 16 & 16 & 15 & 12 & 12 & 12 & 19 & 15 & 5 \\
\hline C_6 & 21 & 1 & 16 & 13 & 11 & 17 & 3 & 22 & 20 \\
\hline C_7 & 11 & 2 & 10 & 4 & 21 & 14 & 4 & 21 & 10 \\
\hline C_8 & 24 & 19 & 11 & 9 & 19 & 9 & 23 & 14 & 9 \\
\hline C_9 & 2 & 5 & 2 & 15 & 2 & 2 & 9 & 8 & 1 \\
\hline C_10 & 10 & 20 & 20 & 18 & 16 & 20 & 13 & 23 & 15 \\
\hline C_11 & 17 & 24 & 23 & 24 & 24 & 22 & 24 & 9 & 24 \\
\hline C_12 & 6 & 3 & 5 & 11 & 10 & 5 & 17 & 11 & 7 \\
\hline C_13 & 7 & 11 & 6 & 22 & 17 & 10 & 10 & 19 & 21 \\
\hline C_14 & 3 & 4 & 4 & 8 & 1 & 4 & 20 & 20 & 11 \\
\hline C_15 & 8 & 10 & 22 & 7 & 14 & 19 & 14 & 1 & 16 \\
\hline C_16 & 22 & 17 & 12 & 14 & 6 & 18 & 22 & 6 & 8 \\
\hline C_17 & 15 & 14 & 7 & 19 & 13 & 6 & 8 & 10 & 22 \\
\hline C_18 & 18 & 22 & 19 & 5 & 15 & 21 & 7 & 16 & 12 \\
\hline C_19 & 5 & 8 & 1 & 16 & 9 & 1 & 6 & 3 & 4 \\
\hline C_20 & 13 & 21 & 18 & 6 & 18 & 13 & 21 & 12 & 19 \\
\hline C_21 & 14 & 13 & 14 & 17 & 7 & 8 & 15 & 17 & 13 \\
\hline C_22 & 12 & 12 & 13 & 20 & 8 & 11 & 11 & 7 & 14 \\
\hline C_23 & 23 & 9 & 8 & 23 & 22 & 7 & 18 & 13 & 6 \\
\hline C_24 & 1 & 15 & 17 & 1 & 20 & 16 & 12 & 18 & 18 \\
\hline
\end{tabular}

Further calculations will be illustrated by the example of 2018 data. The correlation matrix of metric indicators is shown in Table 4, and the matrix of Spearman's correlation coefficients between metric and nonmetric indexes is presented in the Table 5 .

Next, we use the principal component method. The values of factor loadings are presented in Table 6 . We also add to this table the values of the weight coefficients of the partial indicators for the construction of the integral 
index, calculated taking into account the correlation coefficients of Table 4.

Table 4. Values of correlation coefficients for metric indexes for data of 2018.

\begin{tabular}{|c|c|c|c|c|c|}
\hline \multirow{2}{*}{ Index } & \multicolumn{5}{|c|}{ Values } \\
\cline { 2 - 6 } & $X_{1}^{(1)}$ & $X_{2}^{(1)}$ & $X_{3}^{(1)}$ & $X_{4}^{(1)}$ & $X_{5}^{(1)}$ \\
\hline$X_{1}^{(1)}$ & 1 & 0.0829 & 0.4376 & 0.6643 & -0.0203 \\
\hline$X_{2}^{(1)}$ & 0.0829 & 1 & 0.1120 & 0.0564 & 0.1093 \\
\hline$X_{31}^{(1)}$ & 0.4376 & 0.1120 & 1 & -0.0198 & -0.1201 \\
\hline$X_{4}^{(1)}$ & 0.6643 & 0.0564 & -0.0198 & 1 & -0.0278 \\
\hline$X_{5}^{(1)}$ & -0.0203 & 0.1093 & -0.1201 & -0.0278 & 1 \\
\hline
\end{tabular}

Table 5. Values of Spearman's correlation coefficients between metric and non-metric indexes for data of 2018 .

\begin{tabular}{|c|c|c|c|}
\hline \multirow{2}{*}{ Index } & \multicolumn{3}{|c|}{ Values } \\
\cline { 2 - 4 } & $X_{1}^{(2)}$ & $X_{2}^{(2)}$ & $X_{3}^{(2)}$ \\
\hline$X_{1}^{(1)}$ & -0.0157 & 0.2913 & 0.1309 \\
\hline$X_{2}^{(1)}$ & 0.0878 & 0.1470 & -0.0061 \\
\hline$X_{31}^{(1)}$ & -0.0920 & 0.2850 & 0.3237 \\
\hline$X_{4}^{(1)}$ & 0.1454 & 0.0737 & -0.0393 \\
\hline$X_{5}^{(1)}$ & -0.1191 & -0.1235 & -0.2417 \\
\hline
\end{tabular}

Table 6. Values of factor loadings for first principal component and recalculated weight coefficients for data of 2018.

\begin{tabular}{|c|c|c|c|c|c|}
\hline Index & $U_{1}$ & $U_{2}$ & $U_{3}$ & $U_{4}$ & $U_{5}$ \\
\hline First principal component & 0.70 & 0.16 & 0.39 & 0.57 & -0.07 \\
\hline Weight coefficients & 0.29 & 0.03 & 0.40 & 0.22 & 0.06 \\
\hline
\end{tabular}

Therefore, the composite index constructed by the rule of the weighted additive convolution like formula (6) has the form:

$$
I_{1}=0.29 U_{1}+0.03 U_{2}+0.40 U_{3}+0.22 U_{4}+0.06 U_{5} .
$$

Composite indexes for the data of 2017 and 2016 are calculated similarly and results are as follows:

$$
\begin{aligned}
& I_{2}=0.42 U_{1}+0.26 U_{2}+0.25 U_{3}+0.06 U_{4}+0.01 U_{5} \\
& I_{3}=0.38 U_{1}+0.10 U_{2}+0.44 U_{3}+0.07 U_{4}+0.01 U_{5}
\end{aligned}
$$

The analysis of the results shows that the composite indexes have some differences in the values of the weight coefficients. The most significant indicators are the Index of the actual volume of GRP in the previous year prices and Industrial production index. The calculated values of the composite index and the rank of each region in the corresponding time period are presented in Table 7 . Graphical interpretation of results is shown in Figure 1.

The sustainable development of the region's economy must be matched by an increase in the values of the composite index. According to the presented results analysis, the value of the composite index of economic development doesn't have a clear tendency of changes for the vast majority of Ukraine's regions, which leads to the conclusion that the economy of the regions doesn't meet the conditions of sustainable development. Exceptions are only Kyiv, Kirovograd, Mykolaiv, Poltava, Sumy,
Cherkasy and Chernihiv regions. However, the conclusion about the sustainability of economic development for these regions may not be true.

\begin{tabular}{|c|c|c|c|c|c|c|}
\hline \multirow[b]{2}{*}{$\begin{array}{l}\text { Cod } \\
e^{-1}\end{array}$} & \multicolumn{2}{|c|}{2018} & \multicolumn{2}{|c|}{2017} & \multicolumn{2}{|c|}{2016} \\
\hline & $\begin{array}{c}\text { Composi- } \\
\text { te index } \\
\text { values }\end{array}$ & \begin{tabular}{|c|} 
Rank \\
of re- \\
gion
\end{tabular} & $\begin{array}{c}\text { Composi- } \\
\text { te index } \\
\text { values }\end{array}$ & $\begin{array}{l}\text { Rank } \\
\text { of re- } \\
\text { gion }\end{array}$ & $\begin{array}{c}\text { Composi- } \\
\text { te index } \\
\text { values }\end{array}$ & $\begin{array}{l}\text { Rank } \\
\text { of re- } \\
\text { gion }\end{array}$ \\
\hline C 1 & 0.73 & 7 & $\begin{array}{l}0.79 \\
\end{array}$ & 8 & 0.41 & 6 \\
\hline C 2 & 0.55 & 14 & 0.70 & 14 & 0.34 & 9 \\
\hline C 3 & 0.51 & 15 & 0.71 & 13 & 0.17 & 21 \\
\hline C 4 & 0.39 & 18 & 0.59 & 20 & 0.31 & 14 \\
\hline C 5 & 0.66 & 10 & 0.83 & 4 & 0.41 & 5 \\
\hline C_6 & 0.69 & 8 & 0.74 & 10 & 0.18 & 20 \\
\hline C 7 & 0.38 & 19 & 0.84 & 3 & 0.19 & 18 \\
\hline C 8 & 0.76 & 5 & 0.89 & 2 & 0.10 & 23 \\
\hline C 9 & 0.81 & 1 & 0.64 & 16 & 0.40 & 7 \\
\hline C 10 & 0.76 & 4 & 0.56 & 21 & 0.55 & 2 \\
\hline C 11 & 0.17 & 24 & 0.06 & 24 & 0.98 & 1 \\
\hline C_12 & 0.64 & 11 & 0.77 & 9 & 0.21 & 16 \\
\hline C 13 & 0.63 & 12 & 0.55 & 23 & 0.46 & 3 \\
\hline C 14 & 0.26 & 23 & 0.81 & 6 & 0.45 & 4 \\
\hline C_15 & 0.77 & 3 & 0.60 & 19 & 0.20 & 17 \\
\hline C 16 & 0.30 & 22 & 0.82 & 5 & 0.18 & 19 \\
\hline C 17 & 0.74 & 6 & 0.64 & 17 & 0.10 & 24 \\
\hline C_18 & 0.46 & 17 & 0.90 & 1 & 0.29 & 15 \\
\hline C 19 & 0.50 & 16 & 0.63 & 18 & 0.34 & 10 \\
\hline C 20 & 0.35 & 21 & 0.80 & 7 & 0.31 & 13 \\
\hline C 21 & 0.35 & 20 & 0.74 & 11 & 0.37 & 8 \\
\hline C 22 & 0.78 & 2 & 0.56 & 22 & 0.32 & 11 \\
\hline C 23 & 0.67 & 9 & 0.67 & 15 & 0.14 & 22 \\
\hline C 24 & 0.59 & 13 & 0.73 & 12 & 0.31 & 12 \\
\hline
\end{tabular}

Table 7. Values of the composite index and the rank of each region for 2016-2018.

The obtained results can be explained by the significant variability of metric indicator' values for the Ukraine's regions over the studied period of time. More accurate results may be obtained by constructing a single composite index for the entire data sample. However, this raises the problem of calculation of the weights of initial indicators. Taking into account the deep interconnections between all regional subsystems, it is also appropriate to consider social and environmental indicators to evaluate the economy of the region, in particular as a non-metric component of the set of initial data. The solution of these problems is the subject of further research.

\section{Conclusions}

Assessing the regions' economy in the context of ensuring their sustainable development remains a topical task, both at the state level and for individual entities.

Conducted studies have shown widespread use of the methodology of comprehensive evaluation in solving this task. The article deals with the approach to design a composite index for assessing the level of economic development of a region by using a weighted convolution of initial indicators. The scientific novelty of the proposed approach is the use of both metric and non-metric indicators. The metric component is used directly to form the values of the composite index, and the nonmetric 
component is used to calculate the weight coefficients of the components of the composite index.

The practical implementation of this approach has shown that the economy of the vast majority of Ukrainian regions does not meet the principles of sustainable development.
The findings can be used as a basis for shaping the development strategies at both regional and national levels, as well as for evaluating the implementation of economic, social and environmental aspects of sustainable development in the regions.

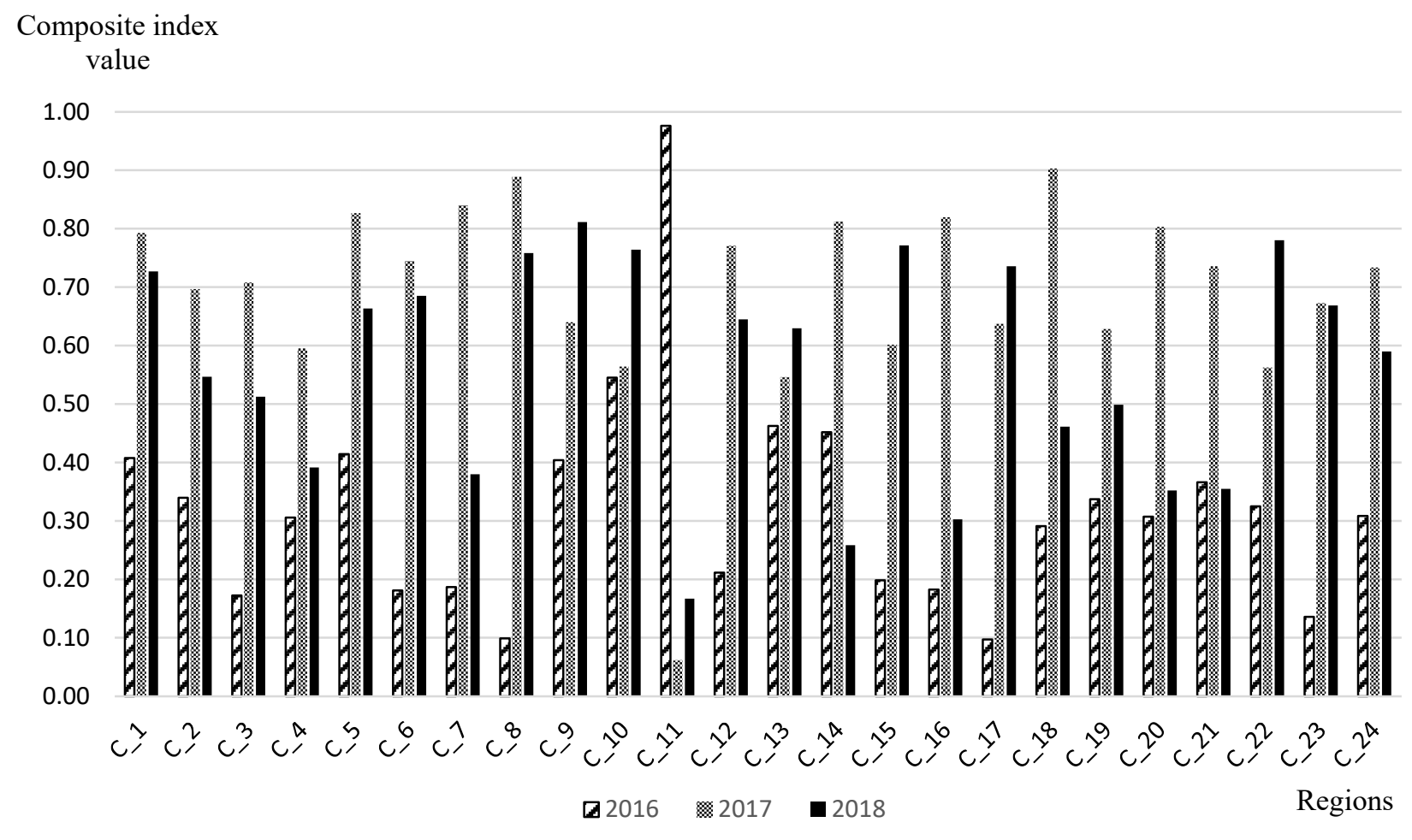

Fig. 1. Graphical interpretation of values of composite index for regions.

\section{References}

1. United Nations. Department of Economic and Social Affairs Disability. Sustainable Development Goals (2015),

https://www.un.org/development/desa/disabilities/en vision2030.html. Accessed 27 Dec 2019

2. Law of Ukraine "On the Strategy of Sustainable Development of Ukraine up to 2030" (2018), http://search.ligazakon.ua/1_doc2.nsf/link1/JH6YF0 0A.html. Accessed 27 Dec 2019

3. Order of President of Ukraine "On Strategy of Sustainable Development “Ukraine - 2020” (2015), https://zakon.rada.gov.ua/laws/show/5/2015. Accessed 27 Dec 2019

4. A.M. Zhuchenko, Poniattia staloho rozvytku v suchasnii ekonomitsi (The Concept of Sustainable Development in Modern Economy). Global and National Problems of Economy 13 (2016)

5. Sh.A. Omarov, Otsinka staloho rozvytku rehioniv Ukrainy (Evaluation of Sustainable Development of Regions of Ukraine). The Problems of Economy 3 (2014)
6. I.V. Horiana, Formuvannia metodyky otsiniuvannia stalosti rozvytku rehioniv (Formation Evaluation Methods Sustainability of Regional Development). Ekonomichnyy Analiz 14(1) (2013)

7. V.G. Garkavaya, Integrirovannaya ocenka ustoychivosti razvitiya regionov (Integrated Assessment of Regional Development Sustainability), http://www.rusnauka.com/CCN /Economics/13_garkavaja.doc.htm. Accessed 05 Jan 2020)

8. O.O. Nesterenko, Indykatory otsinky rivnia staloho rozvytku ta yikh vplyv na pokaznyky intehrovanoi zvitnosti (Sedimentary Development Evaluation Indicators and their Effect on Integrated Reporting Indicators). Scientific Bulletin of Uzhhorod University, Series “Economics" 15(2) (2017)

9. K.A. Artiushok, Kryterii ta indykatory ekonomichnoi bezpeky i zbalansovanoho rozvytku rehionu (Criteria and Indicators for Economic Security and Balanced Development of the Region). Balanced Nature Using 3 (2016)

10. O. Churikanova, Analiz indykatoriv staloho rozvytku (The Analysis of Sustainable Development Indicators). Ekonomika ta derzhava 2 (2017)

11. P. Mederly, P. Novacek, J. Topercer, Sustainable Development Assessment Quality and Sustainability 
of Life Indicators at Global, National and Regional Level. Foresight 5(5) (2003). doi:10.1108/14636680310507307

12. H. Rahma, A. Fauzi, B. Juanda, B. Widjojanto, Development of a Composite Measure of Regional Sustainable Development in Indonesia. Sustainability 11(20), 5861 (2019). doi:10.3390/su11205861

13. A.E. Pravitasari, E. Rustiadi, S. P. Mulya, L. N. Fuadina, Developing Regional Sustainability Index as a New Approach for Evaluating Sustainability Performance in Indonesia. Environment and Ecology Research 6(3) (2018). doi:10.13189/eer.2018.060303

14. B. Bakri, E. Rustiadi, A. Fauzi, S. Adiwibowo, Assessment of Regional Sustainable Development in Indonesia. International Journal of Humanities and Social Science 6(11) (2016)

15. C. Villeneuve, D. Tremblay, O. Riffon, G.Y. Lanmafankpotin, S. Bouchard, A Systemic Tool and Process for Sustainability Assessment. Sustainability 9(10), 1909 (2017). doi:10.3390/su9101909

16. Y. Huan, H. Li, T. Liang, A New Method for the Quantitative Assessment of Sustainable Development Goals (SDGs) and a Case Study on Central Asia. Sustainability 11(13), 3504 (2019). doi:10.3390/su11133504

17. P. Hryhoruk, N. Khrushch, S. Grygoruk, The Rating Model of Ukraine's Regions According to the Level of Economic Development. Periodicals of Engineering and Natural Sciences 7(2) (2019). doi:10.21533/pen.v7i2.555.g338

18. P. Hryhoruk, N, Khrushch, S. Grygoruk, Model for Assessment of the Financial Security Level of the Enterprise Based on the Desirability Scale. CEUR Workshop Proceedings 2422 (2019), http://ceurws.org/Vol-2422/paper14.pdf. Accessed 05 Jan 2020

19. Monitorynh sotsialno-ekonomichnoho rozvytku rehioniv za 2018 rik (Monitoring of socio-economic development of regions for 2018) (2019), www.minregion.gov.ua/wp-content/uploads/2019/ 05/Reytingova-otsinka-za-2018-rik-prezentatsiynimateriali.pdf. Accessed 24 Dec 2019

20. Monitorynh sotsialno-ekonomichnoho rozvytku rehioniv za 2017 rik (Monitoring of socio-economic development of regions for 2017) (2018), http://ndo.lg.ua/filereader/index/155/50210a698c44d 89fb9c06f3a80de5474. Accessed 24 Dec 2019

21. Derzhavna sluzhba statystyky Ukrainy (State Statistics Service of Ukraine) (2019), http://www.ukrstat.gov.ua/. Accessed 24 Dec 2019 